\title{
Post-Yugoslav spaces between defective democracies, authoritarianism, and kleptocracies
}

\author{
Faruk Hadžić, \\ Independent researcher, Bosnia and Herzegovina, BSc Psychology, Economics, MSc Security Studies, Criminal \\ Justice and Law Enforcement, MBTA Diploma, Mindfulness-based Transactional Analysis \\ * faruk.hadzic01@gmail.com
}

\begin{abstract}
In post-Yugoslav spaces, democracy has not been won by independent and robust social groups that can act as a counterweight to the state structure, with formed interests that act "transformatively"; not directing political change and form the basis of political pluralism. In the processes of political and social transformation of society, pragmatism is a dangerous thing, and the apparent tendency of key political actors to follow the "speech of Europe" in their daily political practice without taking into the content. Ethnonationalism does not bring political scenes a socioeconomic system that would already be independently formed, with appropriate bearers of transformative interests and competing "projects" of the new order. Therefore, the worst uncertainty and fragility can slow down the normalization process and other unplanned consequences. The class of nationalist capitalists, politicaleconomic oligarchies, during the conflicts, takes control of the state apparatus and ownership of economic resources, constituting "nation-states"; unilateral expropriation presented as a self-legitimizing act by which the whole society realizes its being in the form of sovereignty and embodies itself by constituting its "nation-state". Within the notion of "captured states," we can speak from the social property, which is privatized by post-war "tycoons;" supporting authoritarian rulers linked to kleptocracy as a strategy to maintain stability undermines the EU accession process. Civil resistance is not progressive, and all should define life in a democratic society. It is an urgent task of building a civic or democratic political culture, which is inconceivable without a built civil society. Even the banal level of democracy will not survive for a long time, and more countries are moving towards unequivocal authoritarianism and pure illiberalism.
\end{abstract}

Keywords: Former Yugoslavia, kleptocracy, authoritarianism, defective democracy, political culture, civil society DOI: $10.7176 / \mathrm{IAGS} / 86-04$

Publication date:September $30^{\text {th }} 2020$

\section{Introduction}

The Balkans' concept, metaphors of constant divisions, conflicts, and confusions, traditionally includes the high antagonism and wars. The conflicts that took place in Yugoslavia, the war in Bosnia and Herzegovina - BiH (19921995), Kosovo (1998-1999), Croatia (1991-1995), the ethnic conflict in Macedonia in 2001 are described as intense and long-lasting. It also brought many political, security, social and economic consequences that these post-Yugoslav countries, or the countries of the Western Balkans, still face today. The tragic circumstance for all Balkan nations and states is that peace, more precisely non-warfare between them, now as in the past, is guaranteed only by the great powers. Nevertheless, that kind of guarantee leads to colonial, protector, and occupation "peace." These societies structurally destroyed and antagonized ${ }^{1}$, must be very conflicted so that there is no necessary "infrastructure" of a culture of peace and sustainable development. We have had a frequent rise of authoritarians and arbitrary recourse to the government; human rights violations and the state have failed to balance the relationship between state policy and civil society, which, together with nepotism and corruption, weakens the efficiency of state bodies. Western Balkans states are often unable to establish civilian control over security systems, much less to restore inappropriate flows of economy and political decision-making, the distribution of power by expected, legal, institutional flows. In Southeast Europe, hybrid democracies, kleptocracies, and corrupt states have become entrenched today. If we analyze local wars' material side, we see that they are intertwined with the global economy. It is particularly noticeable in those areas that were the subject of Jean and Rufin's analysis (1996), namely the international embargo, the diaspora, international aid, and organized crime. Moreover, former Yugoslavia orders based on ethnic-violence turned into open war economies and entering into dynamic and symbiotic relations with illegal global markets and liberal market structures. Within the notion of "captured states," we can speak from the social property, which is often privatized by "tycoons" in captured states. The class of nationalist capitalists, political-economic oligarchies, during the conflicts, took control of the state apparatus and

\footnotetext{
${ }^{1}$ See: the Berlin daily Der Tagesspiegel published an extensive article entitled 'What is the situation in the Balkan countries today?', In which it also deals with Croatia. Paunović P. https:/www.tportal.hr/vijesti/clanak/nijemciskenirali-ex-yu-drzave-25-godina-nakon-pocetka-rata-u-bih-gdje-je-tu-hrvatska-20170403 4.4.(2017)
} 
ownership of economic resources, constituting "nation-states"; unilateral expropriation presenting as a selflegitimizing act. The presence of capitalism as the ruling model requires the presence of some form of nationalism and national identity- where a certain capitalist elite pragmatically chooses to build a nation-state, to effectively mobilize and homogenize the rest of society on its platform. Local orders based on ethnic-violence turned into open war economies and entering into dynamic and symbiotic relations with illegal global markets and liberal market structures. Within the notion of "captured states," we can speak from the social property, which is often privatized by post-war "tycoons" in captured states, and taking active funds is possible due to legal omissions in the process of transition. Thus, the well-known phrase bribery and corruption, which is an integral part of the Balkan reality, has paradoxically become an appropriate mythological image that delegitimizes the Balkan disordered or post-communist corrupt transitional collectivity. (Vujić, 2019) In general, only those who have funds, de facto, and not only formal or institutional influence, weapons, de facto power, only these actors can "deliver results," and in former Yugoslavia, such actors are largely criminalized or are very close to a crime. Several examples illustrate the above. Simultaneously, unstable societies, including the societies of the former socialist countries of Central and Southeast Europe, are mainly marked by discussions about the political structure and political processes. In the former Yugoslavia, in addition to the apparent problems of inequality, corruption, and fear politics faced by societies, in terms of the development of participation political culture, there are also historical narratives that affect the development of voter awareness of processes within the country that are critical.

Schmitt's (1923) theory of the crisis of representative democracy seems very modern even now. Namely, according to him, a political decision cannot be reached by discussion, a critical means of representative bodies, and it is realistic to expect paralysis in representative bodies, although not necessarily polarization. In addition to the general modalities and the reasons for the state's weakness, another phenomenon can be singled out - selectively weak. It is weak only in specific segments. That is, the political elite, balancing between the pressures of the international community and the pressures of the public, seeks to weaken the state's functions in segments that are not important for the survival of the regime, while late action is expressed comes to government interests. (Deudney, 2004) In addition to the marginalization of legislation, there is pressure on the judiciary, which the ruling party seeks to subordinate to its own needs - bribery, co-optation, and various forms of persecution.

In the Balkans, democracy is just another means to an end, but it is not an end. Many of the symptoms of the crisis that European democracies are currently experiencing have been developing, expressing and consolidating for years in the southeast of the continent: the crisis of democracy in Southeast Europe is visible to everyone, and "the idea of the liberal-democratic consensus no longer exists" (Bieber, 2017). At the same time, this crisis is not the result of acute depression but developed during a long malicious process.

A specific (extremely negative) characteristic of the post-Yugoslav space is that religions are identified with nations (majority). Fear of losing identity within multi-national communities, such as Yugoslavia, after disintegration led to the sudden "emergence" of antagonistic individual national identities, becoming indivisible and exclusive. Criminal actors' circular actions and the conditions of new international actors are often attributed to mere ethnic theories that are applied continuously in the Balkans analysis. The most critical question is how all the ruling systems that have emerged on the scene are in their essence of ethnopolitics. The answer to that question lies in the constitutive role of war for every policy. (Bhabha,1990:128)

M. Hein and A. Frustorfer (2016) analyzed several statistics and indicators that measure democracy according to different parameters: developmental, social, and the rule of law. All the countries of Southeast Europe, except for Kosovo, regardless of whether they are members of the EU or not, have recorded a constant downward trend over the past ten years. It concerns a physical deterioration. However, even in the case of subjective parameters, such as citizens' trust in society's parliaments and institutions, the same tendency is shown among the countries of the region that are not yet members of the EU or, as in Croatia, which is only members for a short time, the crisis of democracy is accompanied by a more moral crisis of values orientation. Moreover, in this confusion, strong leaders often provide vital support with simple messages derived from national history. Furthermore, nationalism unites communities under the leadership of, admittedly, democratically elected, but leaders who act autocratically.

Political structures in the region are left or right-wing, sometimes opposing each other, and sometimes cooperating in networked mutual support systems. However, very often, abuse by the government destroys the essence of democracy. The dominant mantra, which is repeated continuously in the region's politics, is "EuropeEuropeanization," and the moral content of "European-Europeanization" is primarily pushed into the background vaguely present, or completely lost. As long as we act in the name of "Europeanization" and "democratization," anything is possible. All of the above is contained in the fact that international support is given to "political pragmatists" who oppose "rigid legalists" throughout the Balkans, and pragmatism is in the process of political 
and social transformation of society. Meanwhile, states in the region have become "trapped" or "kidnapped" by private interests after controversial privatizations and the considerable influence of illegally enriched individuals. (Teokarević,2009)

At the same time, the selection of "undemocratic" states is best illustrated by selected twelve indicators of the Peace Fund, which cover a wide range of risk factors for state failure - demographic imbalance, social discontent, unequal development, economic crisis, the delegitimization of power, widespread corruption, and criminal behavior, the inability to collect taxes and attract the support of citizens, as well as environmental degradation and brain drain. Nationalist ideologies and identity politics affect socioeconomic stalemate; economic migrations from the former Yugoslavia are among Europe's highest. (Eurostat,2017)

\section{Defective democracies or Autocracies}

Authoritarianism is versus liberalism. Authoritarian gender means a gap towards political democracy, acceptance of hierarchy (including an undemocratic order based on the national leader's authority, for example), belief in a healthy state that is the guarantor of solving political and economic problems with national exclusivity. Liberalism is the opposite, accepting the principles of the liberal economic order of private property, markets, economic and political freedom, and non-acceptance of authoritarian and nationalist ideologies. Over half of all the new electoral democracies represent specific variants of diminished sub-types of democracy, which can be called defective democracies - starting from the root concept of embedded democracies, which consists of five interdependent partial regimes (electoral regime, political rights, civil rights, horizontal accountability, sufficient power to govern). We can problematize that there has been a change in value orientations in this area, by accepting or rejecting groups of attitudes relating to a particular sphere of social action. These are the economic and political organization of society, where different views, value dimensions of economic-political liberalism (rejection or acceptance of the basic principles of liberal society - private property, market, multi-party democracy). One of them is political authoritarianism, which we assume is the opposite of economic-political liberalism and is based on opposition to individual freedoms and statism - the glorification of the state's role. Then there is national exclusivism, which is based on the idea that nations should be separated. that members of different nations cannot live together. (This is just one dimension of the much broader notion of nationalism). In a broader socio-political sense, nationalisms became the leading proponents of the ideology of exclusion, "very quickly became allies in the former Yugoslavia," (Papić,2012), which further weakened and impoverished all others did not support such discourses. In addition to the apparent problems of inequality, corruption, and fear politics faced by societies, in terms of the development of participation political culture, there are also historical narratives that affect the development of voter awareness of critical processes within the country. A fundamental characteristic of civil society from the socialist-communist period is that it was functional in resolving specific common issues and served as a means of political control. Gabriel Almond (1977), hinting at Eastern Europe's upcoming political and social processes, warned long ago that the main problem would be an inappropriate political culture. It was later confirmed in the research ${ }^{1}$ conducted by the European Institute of Sussex in countries about to join the EU.

Institutional capacity is "the ability to formulate and implement policies and make laws; to be managed successfully with a minimum of bureaucracy; to control blackmail, corruption, and bribery; to maintain a high level of publicity and accountability of state institutions; and most importantly, that the laws are enforced. (Fukujama, 2004: 20) Countries are becoming constantly dependent on external factors, as weak, unfinished, and undemocratic state formations that cannot achieve sufficiently autonomous - economic, political, social, national, and security capacities for progress. This claim is supported by the fact that most former Yugoslav states have not reached the development level since the late 1980s, with an increased risk of losing capital in interaction with other countries. Most countries depend on stand-by arrangements with the International Monetary Fund (IMF), and some have an Extended Fund Facility (EFF), which varies over an extended repayment period. Societies are also heavily burdened by the legacy of armed conflict and protracted transitions. Political structures in the region are left or right-wing, sometimes opposing each other, and sometimes cooperating in networked mutual support systems. However, very often, abuse by the government destroys the essence of democracy. The dominant mantra, which is constantly repeated in the region's politics, is "Europe-Europeanization," and the moral content of "European-

\footnotetext{
${ }^{1}$ The research was conducted in 10 countries of Central and Eastern Europe (Poland, Czech Republic, Hungary, Slovakia, Romania, Slovenia, Bulgaria, Latvia, Lithuania, Estonia). Experts studied political institutions' position and their functioning in countries that, after the fall of socialism, showed a clear political will for democratization and integration into the European Union, in the period from 1989 to 2000. today they are all members of the European Union. European Commission, 25 years after the fall of the Iron Curtain, The state of integration of East and West in the European Union, Directorate-General for Research and Innovation Inclusive, Innovative and Refective
} 
Europeanization" is mostly pushed into the background vaguely present, or wholly lost. All of the above is contained in the fact that international support is given to "political pragmatists, "and pragmatism is in society's political and social transformation.

Initially, they can be defined as a kind of hybrid regime, such as competitive authoritarianism, characterized by low horizontal accountability, robust, plebiscitary, and prone to executive power abuses. The main feature of this regime is that formally there are democratic institutions, but very often, there are abuses by the government, which destroys the very essence of democracy. (Lewitsky, Way,2002:53) Democratic institutions are pragmaticallypolitically viewed as a means of gaining and exercising political authority. Those in power very often and, to such an extent, violate formal rules that the regime does not meet even the usual minimum standards for democracy. The elections, while supposed to be free and fair, are, in fact, a "one-horse race" - they deprive the opposition of a chance to win, as the authorities regularly misuse state funds and prevent the opposition from gaining media space. In this context, the election winners acted as if they had received majority support within the pluralistic competition and plebiscitary (Vrcan,1999) support that legitimized them as complete masters of political communities. According to Guillermo O'Donnell (1994), a form of regime close to competitive authoritarianism is "delegate democracy".

In such states, there are signs of competition between stabilizing and modernizing movements, collectively referred to as "development" or "progressive power", and destructive, criminalizing tendencies. However, it is often forgotten that both types of tendencies have internal, essential interests that guide them towards cooperation. The least controversial and most straightforward point of contact between these seemingly opposing social tendencies is focused on the possibility of concretely achieving the goals they have made public as their commitments. For example, progressive political forces must prove that they are achieving specific goals: they are "delivering results" because of their international partners and local support. In that endeavor, they face many obstacles. Namely, they encounter social and even state structures, in which the factual knowledge and means for achieving the results that they proclaimed as their lie in the hands of people who are not members of these progressive forces themselves. For example, in the police and state security services, the expertise and resources for its use are often in the hands of people who are not in the same political "basket" as the democratizing and "progressive" forces in society. The situation is similar in other areas where there are legitimate social goals.

In a symbolic sense, this region may be burdened with a negative ontology that is very difficult to change. (Hadžić, 2020) The nationalization of states prepared the ground for the entry of capitalism - ethnonationalism and ethnoreligious violence played a crucial role as a foundation for criminalization. After controversial privatizations of former Yugoslav economic giants and banks, and the significant influence of the new actors, countries in the region became "captured" by private interests by confiscation of the cultural property of the former Yugoslavia and transfer of that property to the thin layer of war profiteers, the former technocratic layer, the domestic political elite and foreign tycoons." (Tabaković,2007) The author suggests that the primary determinant of the captured state is corruption and a dysfunctional government that cannot implement the reforms necessary for its functioning. In terms of crime, at the highest levels of politics leads to the capture of institutions- "captured state". According to R. Karklins (2007), it is reflected in the takeover of the entire state by cartels consisting of political elites and economic oligarchs. They are captured and made politically expedient, but not socially influential, by legislative, executive, judicial instances, and regulatory agencies and prosecuting authorities, which, depending on the political interest, abuse the principle of prosecution opportunism." (Stojiljković in Zgodić 2015: 134). The European Commission, which usually uses diplomatic language, also stated in 2019. report that the Western Balkans countries show clear elements of state capture, including links to organized crime and corruption at all levels of government and administration and a strong intertwining of public and private interests. Montenegro and Serbia are in accession negotiations with the EU. In 2020, it was agreed to start negotiations with Northern Macedonia and Albania. BiH has applied for membership, and Serbia is blocking any progress by Kosovo. It is one side of the EU's enlargement process. However, how are things with the values advocated: democracy, the rule of law, and sustainable development in practice? The assessment of these countries by the Freedom House organization from 2018, Serbia as a semi-consolidated democracy, BiH, Kosovo, and Macedonia as transitional, hybrid regimes; regimes that have elements of democracy but also authoritarianism, speaks enough about the fact that these countries face fundamental problems, which diminishes their political, social, and economic opportunities in the modern world. The characteristics listed for this area have significantly influenced the assessment of these countries as weak and that issues such as the status of the country itself have dominated in recent years in the operation of this region to other important priorities such as economic underdevelopment EuroAtlantic orientation. Furthermore, in a study by the Bertelsmann Foundation ${ }^{1}$, experts claim that democracy in

\footnotetext{
${ }^{1}$ https://www.dw.com/sr/defektna-demokratija-na-zapadnom-balkanu/a-17384219 Experts from the Bertelsmann
} 
Southeast Europe is "defective", that governments are abusing their power, and that citizens' dissatisfaction is growing. Dissatisfaction and frustration with government institutions' work are growing in many countries in Central and Eastern Europe. We can problematize that this can be closely related to the EU crisis, caused by the global market and financial crisis. At the same time, EU membership has not yet brought prosperity or a faster economic recovery to the region's citizens. ${ }^{1}$

Ethno-political conflicts hinder political and economic transformation in Bosnia and Kosovo, although Belgrade and Pristina are still in dialogue, and an agreement has been signed on the integration of Kosovo-Serb structures into Kosovo's institutions. The Freedom House 2018 report stated that some indicators such as national democratic governance, the electoral process, civil society, and media independence have deteriorated since 2014. The reasons are precisely in the authoritarian political leadership and the dominance of one political option-the lack of alternatives in society that will improve the country's situation. Interestingly, many refer to the reforms that should come with the attempt to join the EU because it is already known that with such a democratic assessment, many current politicians need to change and include in reforms, not just the attitude towards Kosovo or good relations with neighbors, but also cooperation with The Hague tribunal (ICTY). In Serbia, political life generally takes place outside the game's formal rules, such as the constitution and laws, except when it comes to elections and the fundamental freedoms of citizens. The rule of law does not reside here, and informal institutions, such as clientelism and corruption, dominate. The executive dominates all political life aspects, ignores the constitution and laws, and plays with the legislature and the judiciary and newly established regulatory agencies. Naturally, this situation produces political instability, slows down economic development, and negatively affects the longterm prospects of democracy in the country. (Vladisavljević, 2011: 204) The problems that cause stagnation in democratic capacities and political pluralism stem from the nationalism that is retained in the ruling political parties, based on the political programs of the parties in Serbia. Another problem is the authoritarian political order, driven by nationalism. The leadership type of parties prevails on the political scene, where party leaders and their word are undeniable. Furthermore, the use of violence within Serbia, which presumably included the assassinations of political opponents and independent journalists, calls into question the regime's classification as a defective democracy and suggests an "authoritarian" mode. (Antonić,2002) Simultaneously, the war social environment is not a favorable ground for democratic political culture, because even today, Serbia is facing the consequences of the war and the past that determines it in many segments. The low level of general culture and political culture dominates the party system and public opinion in this country of the Western Balkans, especially when it comes to parties in power and opposition. In Serbia, we notice growing pressure on the media, and freedom of expression, increasing pressure on power division. Here we have an executive that practically completely dominates the legislative processes. Nevertheless, we still cannot define Serbia as an autocracy but as a defective democracy (Donner, 2020). It stems from the fact that the president "on several occasions" influenced decisionmaking and thus "undermined the state-legal order and the system of separation of powers. ${ }^{2}$ Approaching NATO is treated as a taboo subject due to Serbia's 1999 bombing to stop the conflict in Kosovo. This relationship is also reflected in $\mathrm{BiH}$ politics. There is also a declarative commitment to European integration, which is burdened by the Kosovo syndrome. By the Kosovo syndrome, we mean Serbian politics' burden with the belief that joining the EU means renouncing territorial sovereignty. In this way, the EU's demands for better functioning of $\mathrm{BiH}$ are read in the RS. In the relations between $\mathrm{BiH}$ and Kosovo, no aspect can be singled out to function at a satisfactory level. Relations remain in the realm of political rhetoric ${ }^{3}$, and the problem of freedom of movement between $\mathrm{BiH}$ and Kosovo is directly linked to the problem of asymmetric and scarce economic cooperation.

Foundation analyzed 129 developing and transition countries. The study was conducted based on standardized questions, such as: on the possibility of free choice, on the degree of freedom of expression or respect for human rights. Also, under scrutiny were social protection systems, economic success, and the fight against corruption. Finally, the results were evaluated and presented by a country's position under the headings: democracy, a market economy, and quality of government.

${ }^{1}$ That is why European optimism and those political forces that accumulate citizens' dissatisfaction and populist mood are strengthening. "This can be especially seen in the example of Bulgaria and Romania, which joined the EU in 2007.

2 2020, https://www.frontslobode.ba/vijesti/politika/151197/zemlje-zapadnog-balkana-imaju-defektnedemokracije-samo-je-u-bih-demokracija-izrazito-defektna

${ }^{3}$ In RS, Prime Minister Milorad Dodik has threatened to secede from $\mathrm{BiH}$ if Kosovo becomes independent. On February 20, 2008, the president of the non-governmental organization Serbian People's Movement (SNP), "The Choice was Ours," Dane Camkovic, called on Prime Minister Dodik to organize the adoption of a declaration on the declaration of independence of RS. Hina, https://dnevnik.hr/vijesti/svijet/banja-luka-poziv-dodiku-daproglasi-neovisnost-rs.html,2008 
In the EU, politics lean too strongly on differences, whether they are religious, linguistic, ethnic, or cultural. However, due to the growing economic insecurity and the fear of losing national identities in an environment of globalized culture, some have perceived multiculturalism as a threat, particularly during the current Migrant crisis. (Hadžić,2020)

What about policies in the Balkans? Another has replaced one ideology of collectivity; the ideology of nationalism has replaced the ideology of socialism. The basis of such a collectivist pattern is identifying cultural-ethnic and institutional-political identity in which the political community is thoroughly identified with the national or ethnic community. By instrumentalizing the issue of ethnic/national/confessional within the radicalization of political discourse, ethnic homogenization occurs. The result is that ethnopolitical parties remain in power. Ethnic mobilization encourages and spreads a sense of homogeneity and equality and creates a sense of security and power in the collective "We." Therefore, the whole process of ethnic mobilization ends with the imposition of a kind of pre-political equalization of the people and their political elite, which is now expected to lead them through the difficulties of the hostile transitional environment within the highly homogenized former Yugoslav political space. (Hadžić,2020:25)

Thus, with the disintegration of Yugoslavia, the ruling elites' prominent role, of course, and gaining and consolidating power, was to build a national identity but accompanied by great violence based on the most terrible, most aggressive expression of the re-emergence of ethnicity. "Heart" of politics. Friend-enemy is the ultimate degree of intensity of grouping and separation. The author argues that the highlights of the "big state "hegemony Balkan politics are also the moments in which the enemy sees the enemy in real clarity. From the example of the post-Yugoslav space, one could learn a lesson about internal discord and destruction ideologies as inconvenient historical facts in this area: fear of the other (minority/majority discourse) is the greatest enemy human social communities. (Hadžić, 2020: 812) It is known that the social positions of religion and religious communities are more influential if they help determine identity. The stronger their influence on the creation of identity, the higher their influence on political life. Simultaneously, it has proved true that ethnic divisions are more difficult to overcome than religious, social, or cultural divisions within a nation. (Kasapović,2007:141) As in BiH, political polarization is carried out on a confessional/national basis: Muslims gave support to candidates from the Bosniak people, Catholics to those from the Croat people, and Orthodox candidates from the Serb people. It is a permanent crisis state, the inability to create the minimum internal political cohesion needed to build a stable political identity. Within the discourse of defective democracy with the nationalist legitimacy of $\mathrm{BiH}$, it was a special case, because in it in a single formal state framework, they faced three virtual communities, represented by the respective parties, each of which not only claimed the role of the only legitimate representative of the respective ethnonational group but also confirmed that role in free elections. (Pešić,2002) In the BiH's ethnoreligious model, which is formed by agreement of the three constituent peoples, the demographic remnant is unconstitutional. For the most part, a mere constitutional decor appropriately enshrined in the last indent of the Preamble of the discriminatory $\mathrm{BiH}$ Constitution. Therefore, the name "Others" is an unsentimental description of their position in this ethnoreligious divided society.

Furthermore, collective interests dominate citizens' individual preferences in the example of BiH, preventing the development of free debate and the inclusion of non-ethnic elements of society. Besides, on the example of $\mathrm{BiH}$, institutions' strength in terms of the rule of law and good governance was assessed as inferior, with deteriorations noted. This situation's reasons are inconsistent laws, ineffective coordination within institutions and between different government levels, the fragmentation of institutional structures, and the absence of a supreme judicial body. The complexity of the political and legal system in $\mathrm{BiH}$ society is also evident through four separate judicial systems, the state, two Entities, and Brčko District, as an independent territory, while ten cantons in $\mathrm{FBiH}^{1}$ also have their judicial systems. Another issue, expressed in terms of the rule of law and enforceable in practice, is the political influence on the judiciary and its inability to act independently. In $\mathrm{BiH}$, all three ethnopolitical structures pursue containment policies, so "hybrid wars" prevent their necessary transition into three political communities. (Hadžić, 2020:250)

The study argues that Kosovo has the attribute of a proto-state, in the transformation process, as a state that was part of Serbian statehood and based on its unresolved status. Kosovo's transformation process depends not only on its capabilities but also on its neighbors and the international community and its efforts. Kosovo's problems are similar to those of all Western Balkan countries, all the more critical because of its specific issue. Non-recognition of his independence and strained relations with Serbia limit his progress. Democracy in Kosovo is at a standstill,

\footnotetext{
${ }^{1}$ Federation of Bosnia and Herzegovina. (Another entity is the Republic of Srpska and one district-Brčko District)
} 
with government weaknesses best reflected in the inability to overcome internal tensions. National party elites dominate the political scene; there are sharp attitudes of the government and the opposition with a minimal role of non-members in party affairs, a limited direct role of party members in decision making, lack of party factions, weak influence within groups by functional groups like women, youth and retirees, lack of affiliated organizations, hierarchical internal order, simple organizational patterns. The parties are institutionalized but do not have a broad membership. Historical and political circumstances, primarily war events, have contributed to the Balkans, including Croatia, being defined as a "derailed transition," where the nation-state's formation took precedence over democratic change and the problematic legacy of communism and economic backwardness. M. Kasapović states that the war made the transition processes in the country second-rate because the formation and defense of the newly formed state gained a clear advantage over the transformation of political and social life and that Croatia often moved from transitional to war studies, where war not only significantly surpassed transition processes, rather than making them opaque. (Kasapović, 2001: 16) The judiciary was subjected to an officially unrecognized purge carried out according to the criteria of political obedience and ethnic (Serbian) affiliation. (Uzelac,2001:4) According to the political system's characteristics, it is not an authoritarian regime, but according to the policy pursued in that defective democracy, it is very close. The economic situation has only partially improved, thanks to EU funds, in Croatia. However, in the long run, the system has caused the most massive exodus of the population, reducing the tax base and jeopardizing pension health systems. A recent survey (2018) in Croatia shows that the main reasons for mass emigration are "an unorganized and corrupt state." (Jurić,2018)

Slovenia, the first former Yugoslav EU member, since 2004, does not have a high level of corruption, widespread clientelism, partisanship, lack of strategic vision, and is evenly developed. Although the former Slovenian Prime Minister was convicted of corruption, Slovenia has a perception of corruption of over $60 \%$, while Croatia, to $48 \%$.

A quarter of a century after the break-up of Yugoslavia, the rest of Europe was warned that there was a political and economic vacuum in Western Balkans, which could soon turn into a security-political problem. That is why Austria is firmly in favor of giving these countries a critical perspective of EU membership. Compared to a few years ago, EU membership today is less attractive to some Western Balkans countries, some of which are starting to turn their heads towards new partners, such as Russia. Countries such as BiH and North Macedonia, which rely on Russia for oil and gas, are particularly sensitive to Russian incitement to anti-Western and nationalist narratives.

\section{Kleptocracies}

The critique of aristocratic and bourgeois kleptocracy, initiated by Rousseau's initial thesis full of foreboding, was taken over by the French Revolution; it took over her with a bitter enthusiasm from which arose the perilous connection of idealism and resentment. Already with the early socialists, almost expressis verbis meant: the property is theft. Young Marx was at first very sympathetic to the anarchist Pierre-Joseph Proudhon, who coined this infamous phrase and demanded, in the 1840 title deed, the abolition of the old order and the establishment of unions of producers in which there would be no administration. The only power that could oppose the plunder of the future would have to rest on one new socio-psychological invention of "society." That finding would be nothing less than a revolution of the hand he gives. (Sloterdijk, 2010) The fact is that after the Second World War, socialist Yugoslavia became a kind of European success story. Between 1960-1980, it had one of the highest economic growth rates in the world, a decent standard of living, free medical care and education, a guaranteed right to work, one of the most respected passports, one-month paid vacation, a literacy rate of over 90 percent, and a life expectancy of 73 years. In terms of living standards and freedoms ahead of most Eastern European countries and individual branches of the economy ahead of Western European countries. After Tito's death, the biggest problem was that civil democracies did not replace communism, but ethnonational ones. The period characterized as transitional after the wars in the former Yugoslavia should be analyzed as a period in which capitalism is already there, being established by the abolition of social property, workers' self-government, and the withdrawal of the state from the position of equal economic actor. Apart from the interests of international financial institutions, there was another interest, and that was the interest of those who implemented the required measures and created economic policy. The class of nationalist capitalists, political-economic oligarchies, during the conflicts, took control of the state apparatus and ownership of economic resources, constituting "nation-states"; unilateral expropriation presenting as a self-legitimizing act. The presence of capitalism as the ruling model requires the presence of some form of nationalism and national identity- where a certain capitalist elite pragmatically chooses to build a nation-state, to effectively mobilize and homogenize the rest of society on its platform. Local orders based on ethnic-violence turned into open war economies and entering into dynamic and symbiotic relations with illegal global markets and liberal market structures. Thus, domestic monetary policy was, in fact, between the pressure of capital and the interests of political structures. As we know, one of the consequences of this situation was corruption. When we look at countries in transition, it is clear that it is a structural phenomenon. In the case of introducing a capitalist economy of the most liberal type with intense competition, the group of individuals who 
carried out the liberalization itself had a favorable position to facilitate the entry of large capital and make money at the same time. Given the poor prospects of the domestic economy and foreign players' strength, this proved to be the most rational way to acquire start-up capital with which these politicians could start their economic activity or at least provide themselves existentially. A massive level of corruption developed during this period. In this sense, the comprador bourgeoisie's corruption proves to be a structural phenomenon in peripheral economies.

If we analyze local wars' material side, we see that they are intertwined with the global economy. It is particularly noticeable in those areas that were the subject of Jean and Rufin's analysis ${ }^{1}$, namely the international embargo, the diaspora, international aid, and organized crime. Moreover, the former Yugoslavia orders based on ethnic-violence turned into open war economies and entering into dynamic and symbiotic relations with illegal global markets and liberal market structures. Within the already mentioned notion of "captured states," we can speak from the social property, which is often privatized by post-war "tycoons" in captured states. Taking active funds is possible due to legal omissions in the process of transition. Pavlović calls this type of devastation of the country "tunneling of resources from companies" (Pavlović, 2006) where companies are devastated on the transfer of assets and profits in favor of the majority ownership that is already owned by a private company. The very transformation of all states, in most cases, depends on the social strata and actors of power within states. Such is the case in this type of government as well. Most often, society's strata have no interest in carrying out reforms and supporting political and economic transformation. Political and economic change cannot be fully accomplished due to disagreements between the economic and political spheres that would thwart the functioning of democratic institutions, because the consolidation of the democratic order and the establishment of a market economy are in the balance of incompleteness.

Furthermore, the economic approach is not limited to explaining the behavior of those who have power and who are only interested in satisfying their interests (Lock 2002: 268) and indicates that when applied from a theoretical perspective, the system that civil wars are processes with their dynamics. Simultaneously, the critical moment is the ambiguity of the circumstances related to the relationship between the state and the war. This ambiguity cannot be removed, and it will be enough to look at, say, the situation in Serbia in the 1990s: the state becomes an instrument of ruling elites, there is a union of form and regime and constant interference of administration and state, expanded clientelism, Caesarist codes of government, financial oligarchy. It increasingly announces dissatisfaction at the end of the millennium) and the deterioration of the social fabric. Illegal economy, structural adjustment policies conditioned by international financial funds, the reputation of the endeavor market, long-term transition, high unemployment rate, government impregnations with organized crime, socio-political exclusions are factors shaping the socioeconomic climate of the region - the complex political, social, and economic realities and changing expectations (security and stability of states) prolonged the aspirations of individual countries for the process of democratization and integration into the EU and NATO. The result is processes characterized by a lack of transformation, cooperation, security, and general disorganization at the regional and international levels. It created attempts to isolate the Western Balkans from the rest of the political, economic, and even "geographical" Europe as a particular entity that generates only violence and instability. The long-term absence of a political will manifested itself through institutional vacuums after ethnoreligious conflicts, created a strategic basis for developing a fragile state of security and the criminalization of societies. (Hadžić,2020:259) On the example of Bosnia and Herzegovina's post-war situation, M. Pugh showed how strongly political and economic interests are intertwined with controlling over trade and production. Bosnia and Herzegovina is also an excellent example of how the international embargo has enabled the creation of many monopoly positions based on force and how, partly because of these monopolies, war's economic structures greatly hinder the construction of a market order in the postwar period. (Pugh 2002).

A. Peter argued that war economies in places like the Balkans, the Caucasus, and Central Asia are criminalized because they rely on criminal actors and the black market as the primary source of funding and supply, within a close connection between conflict and crime, which gives these conflicts the form of criminalized conflicts. An important economic feature of the war in the former Yugoslavia is the explosion of so-called war profiteers. Since every war is, by definition, a time of abnormal tendencies in all spheres of human life, the most drastic changes in the domain of economic efficiency have taken place. A unique economic feature and most significant impetus for strengthening criminal networks in the Balkans was the tremendous economic opportunity offered by weapons or other war goods, such as fuel, and international humanitarian aid appropriation. In this respect, the war economy's

${ }^{1}$ A pioneering contribution to the paradigm shift, the transition from ethnicity to the economy, was given by a collection that appeared in 1996 under the title "Economie des guerres civiles," edited by Francois Jean and Jean Rufin. It analyzes the participants' economic strategies and interests in the war in a series of well-researched cases. It shows how both those strategies and those interests are firmly connected with global financial processes. 
legacy profoundly affected the post-war processes of social reconstruction. The problems arising from the state's criminalization arise mainly in environments characterized by institutions' weakness and the moral crisis that usually accompanies weak institutions. In the former Yugoslavia political environment, politicians often act without moral responsibility, nor after the lawsuits against them and the publicly announced crimes they committed as officials. Most democratic forces engaged individuals from dubious criminal status, openly known criminals, as their official security, and criminals were often part of political assemblies (Arkan ${ }^{1}$ ). There is almost no prominent politician in the region who has not been accused of abuse of power. Investigations are mostly not completed, and even if there is a trial, it ends with an acquittal. (Hadžić, 2020) While the salaries of parliamentarians in EU countries amount to two or three average salaries, this ratio in $\mathrm{BiH}$ (the highest paid in ex$\mathrm{Yu}^{2}$ ) is as high as eight average salaries, which puts them among the highest in Europe. The profession of "politician" has become a synonym for the best paid social elite, which has the right to "white bread after the expiration of its mandate." ${ }^{3}$

Besides, the constant political, economic, and security crisis have inevitably led to the erosion of institutional structures and the creation of informal social relations, often based on nepotism - a kleptocracy. After controversial privatizations of former Yugoslavia economic giants and banks, and the significant influence of the new actors, countries in the region became "captured" by private interests by confiscation of the cultural property of the former Yugoslavia and transfer of that property to the thin layer of war profiteers, the former technocratic layer, the domestic political elite and foreign tycoons." (Tabaković,2007) The author suggests that the primary determinant of the captured state is corruption and a dysfunctional government that cannot implement the reforms necessary for its functioning. In terms of crime, at the highest levels of politics leads to the capture of institutions- "captured state." According to R. Karklins (2005), it is reflected in the takeover of the entire state by cartels consisting of political elites and economic oligarchs. They are captured and made politically expedient, but not socially influential, by legislative, executive, judicial instances, and regulatory agencies and prosecuting authorities, which, depending on the political interest, abuse the principle of prosecution opportunism." (Stojiljković, 2015: 134). The European Commission, which usually uses diplomatic language, also stated in 2019. report that the countries of the Western Balkans show clear elements of state capture, including links to organized crime and corruption at all levels of government and administration and a strong intertwining of public and private interests. Moreover, the nationalization of states prepared the ground for the entry of capitalism - ethnonationalism and ethnoreligious violence played a crucial role, as a foundation for criminalization. Starting from the war accumulation of capital (profiteering), through the privatizations of the 1990s, to the formation of power within ethnopolitics (especially war parties). During the war in $\mathrm{BiH}$, significant economic capacities were destroyed, and "smugglers became the main suppliers on the market." The black economy in all former Yugoslav countries has left visible changes in the population's social structure; contributed to the impoverishment of a large part of the population. Economic empires of war and post-war actors were created, mainly enriched by the smuggling of excise goods banned from trade. The conflict in $\mathrm{BiH}$ did not differentiate between political and criminal, and there is an interaction of political interests and the interests of the crime itself. (Hadžić,2020)

Within the illegal economy, Montenegro's political elite has suffered numerous accusations from the international community of systematic tobacco smuggling, Kosovo and North Macedonia as a profile of hotspots drugs smuggling from Afghanistan through Turkey, and Serbia's political elite in 2001-2004 under "pro-European reform ruled allegations of supporting Mafia in exchange for their support for "social reforms." ${ }^{4}$ At the same time, in these examples, we see that party elites are willing to tacitly or actively participate in these operations, retaining social power despite society's impoverishment. In all of these cases, criminals have played a key role in strengthening political leaders in countries undergoing a difficult and, in part, unsuccessful "transition." (Köppel, Szekely,2002) The critical problem is the presence of mutual trust between the phenomena of "politicization of crime and criminalization of politics." The distribution of power in a critical region characterized by sociopolitical change

\footnotetext{
${ }^{1}$ Serbian commander of a paramilitary force in the Yugoslav Wars, state agent and state assassin, war criminal, politician, and president of the Obilić football club. He was on Interpol's most-wanted list in the 1970s -1980s for robberies and murders committed in several countries across Europe and was later indicted by the UN for crimes against humanity for his role during the wars. He was assassinated in 2000 before his trial could take place. Danas - Google Boeken,2009

$2 \quad$ Vukomanović,2019,T.https://www.direkt-portal.com/politicari-u-bih-najplaceniji-u-evropi-u-odnosu-nagradjane/

${ }^{3}$ Presidents, prime ministers, ministers, deputies, advisers, and deputies and heads of state institutions can receive a salary by law one year after the end of their term. CIN, Center for Investigative Reporting

${ }^{4}$ These are flagrant examples of synergies between the political elite and organized crime because the police alone could never act like this.
} 
processes has conditioned the synergy of phenomena, and some transitional effects have become structural. Such a historical legacy has persisted to this day and is detrimental to institutional relations and the consolidation of democratic institutions. Blocking the transformation did not mean that systemic changes were frozen, but that the introduction of a full market economy was delayed for members of the ruling group to make the most of their political position economically. ${ }^{1}$ In Croatia, F. Tuđman ${ }^{2}$ and the $\mathrm{HDZ}^{3}$ enjoyed (and exploited) a vast space for arbitrary rule. Imposing the establishment of Croatian statehood and its secession from Yugoslavia as an almost exclusive political topic, the post-communist ruling group gave itself practically free hands to govern all areas of social life. The state took over the previous social ownership of companies and began privatization. Although neither in terms of available capital nor entrepreneurial skills, its protégés and clients could play neither an exclusive nor a significant role (Bišćanić, 2005: 32) the lack of a reliable legal framework, both in privatization and in regulating the relationship between state and private companies, leaves broad scope for state influence on the economic sphere, including systemic corruption. When this kind of cooperation between political elites and criminal organizations is further concretized and developed, this synergy becomes an organized phenomenon of state crime in the same way as during Gonzalez's Government in Spain act of organized state crime.

However, how are things today, with the values advocated: democracy, the rule of law, and sustainable development in practice? In all Southeast European countries, corruption is still constant and one of the biggest opponents of democracy development. Meager turnout in elections in Serbia, Croatia, and Northern Macedonia is an expression of deep distrust of democracy. In addition to the marginalization of legislation, there is pressure on the judiciary, which the ruling party seeks to subordinate to its needs - bribery, co-optation, and various forms of persecution. In general, only those who have "funds, "de facto, not just formal or institutional influence, weapons, de facto power, only these actors can "deliver results," and in weak states, such actors are heavily criminalized or very close to a crime. Three internal dimensions determine the space and chances for political corruption: the existence of privileges that politicians can distribute to small groups, the rich' ability to legally achieve the benefits and longevity of these formed economic and political alliances. These three dimensions increase politicians' willingness to receive illegal funds for their campaigns, tycoons' mood for corrupt politicians.

For Croatia, the example of the judiciary's weakness in the fight against corruption is the clear example of Zagreb Mayor Milan Bandić, who was exposed to "constant accusations of corruption and abuse of office, was arrested once but acquitted each time. It is stated, not by chance, that the mayor of Zagreb was elected to the position for the sixth time in 2017. Current COVID-19 demonstrations in Belgrade, Serbia, have disrupted a President Aleksandar Vučić's ruling party. Northern Macedonia is facing an almost impossible government after an "undemocratic "election campaign. Katica Janeva, a former state attorney, has been accused of corruption. ${ }^{4}$ The Prime Minister of Northern Macedonia, since 2006-2016, Nikola Gruevski has been in exile in Budapest following a corruption ruling conviction. ${ }^{5}$ Albania and Kosovo are in constant crisis mode. Kosovo's elected prime minister, Albin Kurti, is ousted by US intrigue, and Kosovo President Hashim Thaci ${ }^{6}$ faces war crimes charges, which Albanian Prime Minister Edi Rama ${ }^{7}$ sees as an attack on all Albanians, a psalm dispute over the law on freedom of religion between the ultra-reactionary Serbian Orthodox Church and the clique gathered around longtime ruler Milo Djukanovic. ${ }^{8}$

\footnotetext{
${ }^{1}$ It fits in with T. Carothers' warning in Western Civil Society Aid to Eastern Europe and the Former SSSR, European Constitutional Review 55/1999, p. 56. Not only is "transition" not a rapid and one-way process; reforms are often blocked by the actors, not the losers, but precisely those who are at a particular stage of the gain and who are trying to freeze the situation in order to increase their gains.

${ }^{2}$ Following the country's independence from Yugoslavia, he became the first President of Croatia and served as president from 1990 until he died in 1999.

${ }^{3}$ HDZ (Croatian Democratic Community) is the prominent conservative, center-right [ political party in $\underline{\text { Croatia. }}$ ${ }^{4}$ June 18, 2020, A court in North Macedonia on Thursday sentenced ex-Special Prosecution chief Katica Janeva and showman-turned-businessman Bojan Jovanovski to seven and nine years in prison, respectively, for their roles in the so-called "Extortion" case. https://balkaninsight.com/2020/06/18/north-macedonia-jails-ex-specialprosecutor-over-extortion-case/

${ }^{5}$ Nezavisen Vesnik,23/05/2018, https://balkaneu.com/gruevski-sentenced-to-2-years-in-prison-in-tank-case/

${ }^{6}$ Kosovar politician who has been the President of Kosovo[b] since April 2016. He was the first Prime

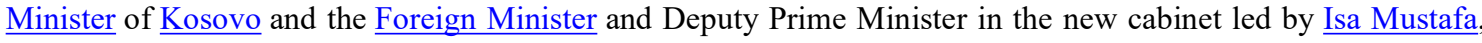
who assumed office on December 12, 2014

${ }^{7}$ Albanian politician, painter, writer, publicist, former pedagogue, and former basketball player,[2] who is currently serving as the 33rd[3] Prime Minister of Albania (since September 13, 2013) and the Minister of Foreign Affairs (since January 21, 2019). Rama has also been the chairman of the Socialist Party of Albania since 2005.

${ }^{8}$ Montenegrin politician who has served as the president of Montenegro since May 20, 2018. He served as prime
} 
Serbian-born economist B. Milanovic wrote on his blog about "multi-party kleptocracies"; political scientist J. Mujanovic described it in his book "Hunger and Anger" as "elastic authoritarianism"; V. Džihić from the Austrian Institute for Foreign Policy noted that the Serbia elections were about "false democracy and the art of illusion."(Steinacker, 2020)

However, some EU countries' situation is not progressive; Romania, Bulgaria, Malta, Cyprus, Hungary, and Poland. Hungarian sociologist B. Magyar, in 2016, described Hungary as a "post-communist mafia state." This particular criterion can be replicated in the "six of the Western Balkans" countries. In Croatia, we have a daily discourse of new economic crime affairs, which unfortunately confirms the famous Balkan paradigm of "who moaned, moaned."1 The Uljanik case received the expected epilogue to introduce the bankruptcy and destruction of a critical segment of the Croatian industry. Namely, the twelve arrested members of the Supervisory Board of Uljanik Shipyard, within a well-developed criminal network, succeeded beyond control and state inspection, shipyards, and the state budget damage by more than 1.2 billion kunas. Bankruptcy and destruction of Croatian shipbuilding and other segments of the industry (steel, metallurgy) (Vujić,2019), in other countries, $\mathrm{BiH}_{\text {precisely }}^{2}$ (energy, water, infrastructure) as strategic segments.

\section{Conclusion}

The Balkans in geographical form through the former Yugoslavia, except Slovenia, has become a frozen entity in history due to the prevailing ethnonational differences and circumstances between and within borders (nationalism, sovereignty, and identities) opposing democratic peace. As in other countries that have experienced and survived the implosion of communist regimes, in post-Yugoslav countries, democracy has not been won by independent and robust social groups that can act as a counterweight to the state structure, with formed interests that act "transformatively"; not directing political change and form the basis of political pluralism expressed through different parties. Ethnonationalism does not bring political scenes a socio-economic system that would already be independently formed, with appropriate bearers of transformative interests and competing "projects" of the new order. In Yugoslavia, this space was predetermined by a high degree of decentralization on the formal institutional level, never achieving social integration and nationalist policy in the institutional constitution of federal units and the informal political mobilization of support for rivals directly-post communist rule. Most often, society's strata have no interest in carrying out reforms and supporting political and economic transformation.

Political and economic change cannot be fully accomplished due to disagreements between the economic and political spheres that would thwart democratic institutions' functioning because of the consolidation of the democratic order and the establishment. On the other hand, within the consequences of disagreement and inability to make decisions in representative bodies, there may be directly democratic, or street support, to entrust authority to one person, or one group or party. Paralysis, therefore, in representative bodies, which the already mentioned Schmidt, within the theory, considers an inevitable characteristic of representative democracy, can lead to an increased role of authoritarian leaders who directly support the people. In the processes of political and social transformation of society, pragmatism is a dangerous thing, and the apparent tendency of key political actors to follow the "speech of Europe" in their daily political practice without taking into the content. In contrast, understanding Balkan institutions as issues of the foreign power in society is distributed between those who dispose of it, those who have the "funds "and ways to protect it, and those who can articulate their political interests, at least verbally, in "European" terms. Some of the Balkan nations are still being formed. However, most have not yet reached the stage of development at which the nation-state, through internal democratic transformation, naturally transforms into a true state of all citizens, equal in everything (although this can be said for many other states, including some who see themselves as role models of liberalism).

minister of Montenegro in three governments from 1991 to 1998, as the president of Montenegro from 1998 to 2002, and as prime minister again from 2003 to 2006, from 2008 to 2010, and from 2012 to 2016. Đukanović is also the long-term president of the Democratic Party of Socialists of Montenegro, originally the Montenegrin branch of the League of Communists of Yugoslavia, which has governed Montenegro since the introduction of multi-party politics.

${ }^{1}$ The phrase 'he who moaned, moaned serves the relationship of the small and the big thief. They praise the big one; they take off the hat of the little one. That phrase became common knowledge when Ljubo Ćesić Rojs (Croatian politician) uttered it in Parliament.

${ }^{2}$ So far, 106 small hydropower plants have been built in $\mathrm{BiH}$. Moreover, at least another 401 are in various stages of planning, preparation, and construction. Isović,M.,2020,https://www.6yka.com/novosti/male-hidroelektrane-ubih-sve-sto-nam-vlasti-i-investitori-ne-zele-rec 
At the intra-social level, in the circumstances of capitalism, in most Balkan societies, there is no visible more developed institutionalized social solidarity, and some class compromises if we problematize that "class peace" is achieved by coercion of primitive and brutal capital, which imposes unquestioning obedience to wage labor. For the most part, the state is on the side of such capital, far from a neutral judge in the objectively existing sharp conflicts of interest of "labor" and capital. Today, however, we can see that economic and political elites are more willing to accept ecological and social catastrophes than significant capitalist system changes. In the Balkans as a whole, we witness the destruction of the public and natural resources (energy, water, infrastructure) and heavy industries such as shipyards and steel mills. Although identical neoliberal policies are applied throughout the Balkans, they differ in intensity because they depend on local circumstances conditioned by different socialist and post-socialist legacies and ethnic-nationalist and religious conflict. The European integration process has been used by local political actors to justify further neoliberal reforms. In a neglected problem area, political culture occupies a particularly important place, understood as a time-changing set of beliefs, values, knowledge, feelings, and attitudes of members of a society towards political objects, processes, and goals for which the actions of historical tradition are intertwined, the structure of political institutions and the principles of functioning of the political system. So, quite specifically, it is an urgent task of building a civic or democratic political culture, which is inconceivable without a built civil society.

No form of rational state was glorified if the authorities allowed themselves everything they could. Often, they, not the individual by their arbitrariness in their actions and anathematizing the individual's protection, themselves opened the door to anarchy and political upheavals. Sin is on the authorities, not on the individual. The Western Balkans continue to face a crisis of representation in which citizens find themselves alienated from public institutions, and more importantly, the Balkan states fail to ensure their citizens' rights and security. At the moment, there is nothing to suggest that a peripheral area like the Balkans, which is still structurally fragile, does not risk instability from the outside - not to mention the tendency to slip into nationalism or severe reversals of a weak state as has already happened between the two wars in order to respond accurately to economic difficulties attention to these issues must not be lowered. Therefore, leaving aside only the persuasion of local situations and integration efforts, although significant, the worst uncertainty and fragility can slow down the normalization process and other unplanned consequences. For plural societies to survive without separatism, it is possible to either assimilate minorities or institutionalize conflicts among social segments through consociational democracy. It recognizes and respects social segments and divisions between them, striving to establish a stable and functional democracy by including plural social segments in the political process. Outvoting smaller segments prevents establishing a veto institution where each of the segments has the right to invoke. Thus, concluding more "alliances with libertarian and democratic forces" against the growing concentration of media in the hands of political elites requires courage, constructiveness, and civilian forms resistance. Nevertheless, there is a possibility to break through this negative tendency and consolidating autocratic structures.

The status quo and lack of qualitative changes maintenance political-interest structures, utterly independent of differences in their proclaimed political-ideological goals. The confrontation with kleptocracy is a condition of all other social changes. The class of nationalist capitalists, political-economic oligarchies, during the conflicts, takes control of the state apparatus and ownership of economic resources, constituting "nation-states"; unilateral expropriation presented as a self-legitimizing act by which the whole society realizes its being in the form of sovereignty and embodies itself by constituting its "nation-state". There are only two possibilities - either underlining the line and a definite deviation from kleptocracy, a definite change, of course, further decline, affecting population dynamics. Within the notion of "captured states," we can speak from the social property, which is privatized by post-war "tycoons;" supporting authoritarian rulers linked to kleptocracy as a strategy to maintain stability undermines the EU accession process. It also discredits the values, credibility, image, and acquis of the EU. Still, political structures in their current positions have little incentive to change. Moreover, they will do more harm than good if they give up clientelism. Paradoxically, politicians who play the nationalist card are often complicit in undermining their country's sovereignty from within or endangering the national interest for personal gain - often through secret agreements with the "enemy" - or the interests of foreign powers.

Citizens of states that emerged from Yugoslavia's disintegration instead of democracies ended up in hybrid democracies and kleptocracies. Although all countries in the region have free voting and multi-party life, citizens are not a political factor; the culture of protest and civil resistance not progressive; civil society is underdeveloped, and all should define life in a democratic society. Political elites have managed to reduce the democratic experience to a somewhat banal level. Thus, it seems that even that banal level of democracy will not survive for a long time and that more countries are moving towards unequivocal authoritarianism and pure illiberalism. To change such a situation, the collective path, citizens must become a far greater and more important factor of political life in the 
region and individual states' political life. The influence and "action" of the international centers of power are becoming necessary and urgent.

\section{Literature}

- Almond, G.,(1977), Political Development in Eastern Europe, Praeger Publishers New York London

- Antonić, S., (2002), Zarobljena zemlja - Srbija za vlade Slobodan Miloševića, Belgrade: Revelation

- Bhabha,H.,(1990),Nation and Narration, 1990,Routledge

- Bićanić, I., (2005), Transformation of Croatia: The Next Step, S. Dvornik, Zagreb

- Carothers, T., (1999), Western Civil-Society Aid to Eastern Europe and the Former Soviet Union, East European constitutional review

- CIN, Center for Investigative Reporting,2019

- Danas - Google Boeken,2009

- European commission, (2014),25 years after the fall of the Iron Curtain, The state of integration of East and West in the European Union, Directorate-General for Research and Innovation Inclusive, Innovative and Refective,

- Eurostat, Migration and migrant population statistics,2017

- Feilcke, A.,2019, Bieber,F.,https://www.dw.com/bs/kriza-demokracije-na-balkanu/a-37778506

- Freedom House, 2018., 2017., 2016., A nation in Transit Bosnia and Herzegovina https://freedomhouse.org/report/nations-transit/2018/bosnia-and-herzegovina

- Freedom House, 2018., 2017., 2016., A nation in Transit Croatia, https://freedomhouse.org/report/nationstransit/2018/croatia,

- Freedom House, 2018., 2017., 2016., A nation in Transit Kosovo https://freedomhouse.org/report/nationstransit/2018/kosovo

- Freedom House, 2018., 2017., 2016., A nation in Transit Serbia https://freedomhouse.org/report/nationstransit/2018/

- Fukuyama F., (2004), State-Building: Governance and World Order in the 21 century, Cornell University Press

- Hadžić, F., Economic crime, abuse of ethnopolitical power and systemic corruption in Bosnia and Herzegovina; Analysis of causes and risks of phenomena, 2020, International Journal of Arts and Social science, Vol 3, Issue 3, http://www.ijassjournal.com/2020/V3I3/41465751935.pdf

- Hadžić, F., (2020), Multiculturalism challenges, and the culture of fear in the Balkans regarding former Yugoslavia, International Journal of Research and Analytical Reviews (IJRAR), Volume 7, Issue 3, http://www.ijrar.org/papers/IJRAR2002606

- Hadžić, F., (2020), The Politicization of Religion and the Sacralized Balkan Nations Regarding Bosnia and Herzegovina, Occasional Papers on Religion in Eastern Europe: Vol. 40, Issue 7, Article 8., https://digitalcommons.georgefox.edu/ree/vol40/iss $7 / 8$

- Hadžić, F.,(2020), The political psychology of extremism; "naturalness" of the phenomenon in the Western Balkans, Technium Social Sciences Journal, Vol. 11(1), September 2020, ISSN: 2668-7798

- Hadžić, F.,(2020), The EU Political Identity Within The Migrant Crisis And The Balkan - Bosnian Route; Xenophobia and Religious Identity, Research, Society and Development, v. 9, n.10, eXX,(CC BY 4.0) | ISSN 2525-3409 | DOI: http://dx.doi.org/10.33448/rsd-v9i10.XX

- Hein, M.Fruhstorfer, A., (2016), Constitutional Politics in Central and Eastern Europe, From Post-Socialist Transition to the Reform of Political Systems, Springer VS

- Hina,2008, https://dnevnik.hr/vijesti/svijet/banja-luka-poziv-dodiku-da-proglasi-neovisnost-rs.html

- 2020,https://www.frontslobode.ba/vijesti/politika/151197/zemlje-zapadnog-balkana-imaju-defektnedemokracije-samo-je-u-bih-demokracija-izrazito-defektna

- Isović,M.,2020,https:/www.6yka.com/novosti/male-hidroelektrane-u-bih-sve-sto-nam-vlasti-i-investitori-nezele-reci

- June 18.2020., https://balkaninsight.com/2020/06/18/north-macedonia-jails-ex-special-prosecutor-overextortion-case/

- Jurić, T., (2018), Emigration of Croats to Germany. Are we losing Croatia? Školska knjiga

- Kasapović, M.,(2001), Democratic Consolidation and Electoral Policy in Croatia 1990-2000, Croatian Politics

- Kasapović, M., (2001), Methodological problem of critique of consociational democracy in Bosnia and Herzegovina, Status, vol. 12

- Kasapović, M.,(2007), Coming out of the plural? The State of Croatian Political Science, Zagreb, Faculty of Political Science

- Karklins, R.,(2005), The System Made Me Do It: Corruption in Post-Communist Societies: Corruption in PostCommunist Societies, 230 pages, Rutledge

- Köppel T., Szekely A., (2002), Transnational organized crime and conflict in Balkan, Boulder, Co, Lynne Rienner Pub 
- Levitsky, S., Way, L.,(2002), The rise of competitive authoritarianism,https://scholar.harvard.edu/levitsky/files/SL_elections.pdf

- Nezavisen Vesnik, 23/05/2018, https://balkaneu.com/gruevski-sentenced-to-2-years-in-prison-in-tank-case/

- O'Donell,G.,(1994), Delegative democracy, Journal of Democracy, Vol. 5, Johns Hopkins University Press

- Papić, Ž.,(2012), Bosna i Balkan: mogućnosti i uslovi oporavka,[Bosnia and the Balkans, possibilities, and conditions for recovery], Bibliography of the Forum Bosnae Issues 1998-2002, Sarajevo, No. 17

- Pavlović, V., (2006), Civil Society and Democracy, Official Gazette, Belgrade

- Pešić, V.,(2002), in the chapter "War for Nation-States" (Serbian side of the war, 2nd edition), Samizdat B92, Belgrade

- Rufin,J., François,J. (1996), Économie des guerres civiles (Economics of Civil Wars), ISBN 2-01-278788-6

- Schmitt, C.,(1923), The Intellectual-Historical Situation of Today's Parliamentarianism, Duncker \& Humblot, Germany

- Steinacker, G.,2020, https://www.dw.com/hr/balkanom-vladaju-kleptokrati-uz-blagoslov-eu-a/a-54321679

- Sloterdijk, P.,(2010),Kapitalismus und Kleptokratie, u: isti, Die nehmende Hand und die gebende Seite: Beiträge zu einer Debatte über die demokratische Neubegründung von Steuern, Suhrkamp, Berlin

- Stojiljković, Z., (2013) Political Corruption and Weak State, Journal of Philosophy and Society, no. 1.

- Tabaković, S.,(2007), Right in the head, Kulin ban, Zagreb

- Teokarević, J.(2009), Democratization of the Balkan Postcommunist Political Systems, Milan Podunavac (ed), State and Democracy, Službeni glasnik i Fakultet političkih nauka, Beograd,

353-371, ISBN 978-86-519-0949.

- Transparency International corruption perception index, 2018, https://www.transparency.hr/hr/clanak/indekspercepcije-korupcije-2018-48-bodova-60.mjesto/718

- Uzelac, A.,(2001), Croatian Judiciary in the 1990s: From State Independence to Institutional Crisis, Croatian Political Science Review, Vol XXXVIII

- Vladisavljević, N., (2011), book: Constitution and Democracy in the Process of Transformation, Chapter: Democracy, Consolidation of Democracy and the Example of Serbia, The University of Belgrade, Faculty of Political Science, Association for Political Science of Serbia

- Vrcan, S.,(1999), Packaging of power: elections in Croatia in 1995 and 1997, Zagreb, Alinea

- Vujič, J.,(2019), https://projektvelebit.com/korijeni-hrvatske-kleptokracije/

- Vukomanović T.,2019,https://www.direkt-portal.com/politicari-u-bih-najplaceniji-u-evropi-u-odnosu-nagradjane/ 